\title{
Corruption in Higher Education in Russia-First Decade of the 21st Century
}

\author{
Sergey Sergeevich Shirin ${ }^{1}$ \\ ${ }^{1}$ Saint Petersburg State University, St. Petersburg, Russia \\ Correspondence: Sergey Sergeevich Shirin, Saint Petersburg State University, 7-9, Universitetskaya nab, 199034 \\ St. Petersburg, Russia.
}

Received: October 10, 2014 Accepted: November 18, 2014 Online Published: January 28, 2015

doi:10.5539/ies.v8n2p160 URL: http://dx.doi.org/10.5539/ies.v8n2p160

\begin{abstract}
The study is based on a methodology proposed by European Association for Education Law and Policy for their research conducted in 2009 and devoted to commercialization, competition and corruption in European education. In the article, the attempt is made to apply their methods to analyze the problems of corruption in Russian higher education system which existed before the adoption of new educational legislation which came into force in 2013. The subjects of examination in this article are: definition of corruption in Russian legislation, system of control of educational institutions in Russia from 2000 to 2009, corruption at the policy level, at the ministerial level, at the university level. The author states that the legislation and court practice in Russia in the first decade of the 21st century enabled educational institutions to do some kinds of activities in corrupted way. Besides that, the legislation and the corpus of case-law were too complicated. Some laws and decisions made by courts and authorities might contradict one another. State-operated and private educational institutions had different rights and abilities. Thus, Russia needed to gather all the norms concerning activities in educational sphere into one law. This law was adopted in 2012 and came into force in 2013.
\end{abstract}

Keywords: HEI, biased allocation of resources, accreditation of universities, bribes, promotion of universities, grants, publicity

\section{Introduction}

The new law "On education in Russian Federation" that was adopted in December 2012 is considered by public opinion and by some experts as the law on commercialization of education which is directed against the excessive governmental control (BBC, 2012). Such control might result in corruption of educational processes and relations. Under contemporary circumstances, an urgent academic issue is the question of corruption of Russian education system which is on the world Top-20 (Pearson, 2012). Does the new legislation bring any novelties into this field? To answer this question, we need first of all to understand to what extent Russian education had been corrupted before the new legislation started to be worked on. This article is an attempt to assess the level of corruption of education in Russia in the first decade of the 21 st century by the example of higher education.

Some scholars have already done their research of some aspects of this problem. Popkova, Chashchin, and Bogdanov (2013) point out that the amplification of the requirements for quality and level of education of the labor force leads to the formation of modern mechanisms of interaction between the labor market and educational services, which is put into practice in using of personnel marketing, which fundamental task is the creation of an attractive image of an enterprise, as an employer, to ensure its human resources activities with optimal quantity and quality, avoiding corruption. Esyutina, Fearon, and Leatherbarrow (2013) highlight some of the quality issues associated with the Bologna process and reflect on how the statements underpin quality of learning and mobility in a European higher education area context. They explore some of the issues raised from the documentation and examine some early experiences and challenges from a leading Russian university as part of a wider examination of higher education in a Russian context. Luk'Ianenko, Polezhaev, and Churliaeva (2013) explain that engineering education in Russia is undergoing reforms, but the history of this form of higher education does not indicate that it will succeed in bringing it into line with current world standards, or even making it more able to contribute at a high level to Russian economic growth. Some aspects of Russian educational policy are mentioned in the publications devoted to the whole spectrum of cultural policy 
(Codagnone \& Filippov, 2000) or to foreign cultural policy (Meshcheryakov, 2014) of Russia. But there are almost no works specially devoted to the issue of corruption of Russian higher education yet, except the studies of the social control of corruption (Borisova, 2014; Osipian, 2014; Luk'yanova, 2012). Academic discourse provides us with no specific conclusions about the extent of corruption of education in Russia under the circumstances of the former educational legislation.

\section{Method}

Among the academic literature devoted to the topic of corruption in education, one can find some works devoted to the assessment of the level of corruption in some other countries during that period of time (Wang et al., 2011; Greaves \& Scicluna, 2010; Rukhadze, 2010). Many of them are based on methodology proposed by the European Association of Education Law and Policy (ELA). Before its annual conference in 2009, this association sent out a questionnaire concerning different aspects of corruption of education to interested people in European countries (ELA, 2009). The answers helped some academics who were members of the association to make their conclusions relevant for different European countries. Russia was not in that list. Here we make an attempt to answer the questions put by ELA meaning Russia as the object of research.

The substantive hypothesis for this article is an assumption that an excessive governmental control over higher education in Russia in 2000-2010 might result in corruption of educational system, processes and relations.

The method of assessment proposed by ELA is based on the following main concepts and variables: definition of corruption in the national legislation, levels of educational system where corruption occurs, benefits that are available for staff in case of corruption, corrupted actors of decision making process in educational institutions, case law, public and media awareness on corruption, Codes of Conduct regarding corruption, external and internal supervision processes, independent institutions (ombudsman and others) and their reports on corruption in education, the percentage of public and private money, autonomy of the universities in administering the budgets, rich and poor universities in the country. Survey of these concepts and variables helps to maintain a systematic and objective interpretation of the corruption of higher education in a specific country.

The first part of this research, which concerned the issues of commercialization of education in Russia in the first decade of the 21st century, was published in 2013 (Shirin, 2013).

\section{Results}

\subsection{Legal Definition of Corruption}

ELA's method begins with the definitions of corruption. Here we define the notion of corruption as the disposal by an official of any resources that do not belong to him or her or of the authoritative (managerial) power and rights entrusted to him or her for personal gain at the expense of the legitimate interests of other persons, of society or state.

The legal definition of the term corruption used in Russia is stated by the Federal Law number 273-FZ from December 25, 2008 "On Combating Corruption". It gives the following definition:

"Corruption:

a) abuse of power, bribery, receiving bribes, commercial bribery or other unlawful use of an individual's official position against the legitimate interests of society and state in order to obtain benefits in the form of money, property or other assets or services of material nature, other property rights for themselves or for third parties or illegal provision of such benefits to that individual by other persons;

b) perpetration of acts mentioned in subparagraph "a" of this paragraph, on behalf of or for the benefit of a legal entity".

\subsection{Where Corruption Occurs in Education}

Corruption at the level of public policy might occur during competitive funding, or during state accreditation of educational institutions. However, there were actually no confirmed cases of corruption in the sphere of competitive financing of education in Russia. The only thing that can be said is that occasionally the large public foundations funding educational institution research projects on a competitive basis, were accused of using a commission of eminent scientists to distribute funds that had a circle of scientist acquaintances that were in need of cash infusions. And that here, personal interests prevailed over the interests of science and education in order not to offend an acquaintance. Actually, grants given by RFBR and RFH (two largest academic foundations), by the President and the Government rarely reached the periphery, settling in the capital. This might be caused by the aforementioned personal interests. However, none of these commissions had been found guilty of corruption. 
In order for a higher school graduate to be considered an expert with higher vocational education (and, hence, be able to take up a number of posts or to get a raise in salary while working at public enterprises), the higher school should give them a higher education diploma that strictly adhered to the state sample. Non-state universities must pass state accreditation to be entitled to issue such certificates. This system might stimulate the corruption.

At the ministerial level (e.g. corruption by administrators, public officials and politicians, accreditation of universities), the increasing number of private educational institutions was accompanied by a sharp intensification of the activities of the administrative apparatus of state university licensing and accreditation. There had been some proceedings initiated by universities against Federal Service officials for Supervision in Education and Science suspected of the extortion of bribes for accreditation. (This Service issued accreditation certificates.) However, it should be noted that practically none of these proceedings resulted in an indictment. Thus, there were no confirmed cases of corruption at the ministerial level.

At the university level, there might be several ways of corruption:

- personnel (secure opportunities or avoid punishment through petty bribes, others, corruption in teacher recruitment and promotion and tenure lowers the quality of public teaching, admissions (parents may pay bribes to ensure their children's school access), graduation (parents may pay bribes to ensure their children's good grades and graduation), private tutoring),

- allocation of resources (to research: public research commissions, private research commissions, internal research commissions),

- publication of results,

- conference participation (conference grants),

- other.

Corruption ranges from bribes in order to be admitted to HEI and to receive good and excellent marks on examinations, to fraudulent schemes of receiving and using budget money, to bribes for the distribution of money allocated for construction and repair (McCarthy \& Puffer, 2013; Wheelock et al., 2011).

Corruption with regards to decisions about the publication of academic works was in Russia between 2000 and 2010 possible because the demand for publishing services exceeded the supply (the number of academic theses, according to the State Library of Russia, increased from year to year, and one had to publish a certain number of articles on the main findings of one's dissertation research in order to get the dissertation accepted to defense). Also, degree seekers were allowed to publish their findings for fees. However, beginning September 1, 2009, The Criteria for Inclusion in the List of Leading Peer-Reviewed Academic Journals and Periodicals in which Major Results of Doctoral and Candidate Dissertations Should be Published, required applicants' manuscripts publication to be unpaid. Thus, this charge because of increasing demand might go to the shadowy financial realm.

\subsection{Benefits Available for Staff in Case of Corruption}

In the Federal Law number 273-FZ from December 25, 2008 "On Combating Corruption," corruption is defined as illegal use of official credentials against the legitimate interests of society and state in order to receive benefits only in money, property or other assets or services of material nature as well as other property rights. Therefore, situations in which, for example, a teacher gives an excellent grade to a rector's son, and the rector in response promotes the teacher to various conferences, lobbies for the publication of the teacher's academic papers, etc., as well as situations in which a rector of a university appoints one provost at the insistence of someone from the Ministry, and the Ministry in response includes the university's journal in the List of Leading Peer-Reviewed Academic Journals and Periodicals, in which Major Results of Doctoral and Candidate Dissertations Should be Published, may not even be recognized as corruption in Russian legal system. So, the question in this wording can be answered unequivocally: the benefits of corruption can be financial only (money and grants - yes, promotion and publicity - no).

However, the Moscow Commission Against Corruption (Regional Office of All-Russia Public Organization) distributed information about cases in which the object of interest could be not material benefits but power resources in a university.

\subsection{Ways of Struggle against Corruption}

From May to September, 2009, the Department of Economic Security of the Ministry of Internal Affairs of Russia monitored the educational system, looking for violations in the sphere of education, especially for the 
embezzlement of budgetary funds and for corruption. On the 15th of October the results of the monitoring were published. In all, the Ministry of Internal Affairs recorded 3117 crimes, including cases of bribery. In addition to bribery, 1343 instances of forgery, more than 300 instances of abuse of power, 74 instances of overstepping of commissions and 33 of misuse of budget funds were revealed.

The scope of bribery has increased significantly in the first decade of 21 st century. A similar operation was carried out exactly one year before, and then for the same period the Ministry of Internal Affairs has recorded 90\% fewer instances of bribery.

The material damage of reported crimes totaled 155.8 million rubles (about 35 million euro). The amount of bribes totaled 22.6 million rubles (about half a million euro). By carefully analyzing these figures, one can deduce that 928 people have taken bribes from May till September. Of these, 495 worked in secondary education, 265 in universities, and 33-in law schools.

In all crimes, criminal cases were opened. Some of them returned guilty verdicts.

Public opinion polls (in particular, Russian survey of 9002 households conducted by the Public Opinion Foundation from 24 November to 8 December 2008, dedicated to education and spending on education, as well as the all-Russia sociological research «Combating Corruption in the Vital Areas of Activities of the State» conducted by the Center for Regional Studies of Institute of Sociology of Russian Academy of Sciences in 2007, and others) show that the public was well-informed about the corruption in the education system. Most Russians, in one way or another, had enough personal experience to judge the corruption in this area. Most Russians were of the opinion that corruption in this sphere was very high. Sometimes it was based on indirect experience (experience of relatives, friends and acquaintances).

Most Russians agreed that corruption was systematic (institutionalized) in Russia. The source of their awareness of the corruption of modern education system was their personal experience, the experience of their friends, acquaintances or relatives, as well as information published in the media. That was not surprising, seeing as the number of publications on corruption was growing yearly.

However, citizens' awareness did not contribute to solving the problem of corruption. On the contrary, the opinion of the total corruption of educators and education administration provoked corrupting behavior by the consumers of educational services. The conviction that the full realization of the constitutional right to education was not possible without paying bribes encouraged education recipients to pay bribes. According to the 2008 survey, the main initiators of gifts to educators, in the opinion of Russians, are pupils' parents and parents' committees.

Code of conduct regarding corruption existed as a bill (introduced to the State Duma by a group of deputies on March 7, 2002) and dealt only with government personnel. A similar document that had legal standing (in contrast to the above mentioned bill) was the Presidential Decree «On Approval of the General Principles of Official Conduct of Government Personnel» signed on August 12, 2002. It also applied to government personnel only.

In education, codes of conduct might be written and enacted in individual educational institutions or at the level of professional communities of some municipalities. However, such codes primarily concerned the rules relating to competition, not corruption.

The criminal code did not directly mention educational corruption. However, acts of corruption in education were crimes under Chapter 30 of the Criminal Code, "Crimes against the state, against the interests of public service and service in local government". This chapter contained the articles "Abuse of authority", "Misappropriation of budgetary funds", "Misappropriation of funds of state budget funds", "Exceeding the authority", "Bribe-taking", "Bribery", "Forgery". In addition, corruption in education might be a crime under Chapter 23 of the Criminal Code, "Crimes against the interests of service in commercial and other organizations." This chapter contained the articles "Abuse of authority" and "Commercial bribery".

The institutional framework for combating corruption in Russia was established by Article 5 of the Federal Law number 273-FZ from December 25, 2008, "On Combating Corruption":

In order to coordinate the activities of federal executive bodies, executive authorities of subjects of federation and local authorities in the sphere of implementation of public policies to counter corruption, bodies might be formed in accordance with a decision by the President of Russia. These bodies were composed of representatives of federal bodies of state power, bodies of state power of subjects of federation and others. The decisions from the committees that coordinate activities in combating corruption were to be enforced by drafts of decrees, orders and instructions from the President of Russia, draft regulations, orders and instructions from the RF Government. 
These drafts were submitted for consideration to the RF President or the RF Government in due course. Acts (i.e. joint acts) of the federal bodies of state power and bodies of state power of subjects of federation might be published if the representatives of these bodies were members of respective bodies which coordinated activities in the field of countering corruption. Upon receipt of any data on corruption offenses, the bodies of anti-corruption activities coordination passed them to relevant state bodies authorized to check such data and make respective decisions in a manner prescribed by law.

Thus, the existence of a special body was authorized by law. In practice, there was a Presidential Anti-Corruption Council. This was an advisory council created by Presidential Decree number 815 dated May 19, 2008 "On measures to combat corruption." The chairperson of the Council was the President of Russia. The main tasks of the Council were:

- preparation of proposals for the President on the formulation and implementation of public policies for combating corruption;

- coordination of the activities of federal executive bodies, executive authorities of the subjects of federation and local authorities of municipalities in the sphere of implementation of state policy on combating corruption;

- monitoring the implementation of activities under the National Anti-Corruption Plan.

Internal anti-corruption bodies of HEIs, as a rule, were not created.

The post of Commissioner for Human Rights (ombudsman) was established by the Constitution of Russia, 1993. Item "d" of Part 1 of Article 103 of the Constitution related the appointment and dismissal of the Commissioner to the jurisdiction of the State Duma. The Commissioner acted in accordance with federal constitutional law. This law was adopted by the State Duma on December 25, 1996.

The position of Commissioner for Human Rights was established in Russia in order to guarantee public protection of the rights and freedoms of citizens, their observance and respect by public bodies, municipal authorities and civil servants. The Commissioner's activities complemented existing means of protection of rights and freedoms of citizens, did not cancel the competence of state bodies of protection and restoration of violated rights and freedoms and did not entail a reconsideration of their competence.

However, the struggle against corruption was missing from the list of main activities of the ombudsman.

There were commissioners for Human Rights in the subjects of federation, too. The same position might be introduced in educational institutions. In addition, on September 1, 2009 the President established the position of ombudsman for children under the President of Russia. His or her powers were wide enough. The Ombudsman, in particular, might receive any materials and obtain necessary decisions from all organizations in the country for the protection of children rights, and also had the right to examine all bills. Similar positions existed in several regions of Russia.

There were no regular reports on corruption in education. Data of large-scale monitoring were published from time to time (such as the audit conducted by Department of Economic Security of the Ministry of Internal Affairs of Russia from May till September, 2009), but these observations were not regular occurrences.

University admissions were, to some extent, centralized. Each university had its own entrance commission, but the entrance test was administered centrally. The results of the Unified State Examination (USE) had the same status as the results of final examinations in schools and entrance examinations in universities and could be recognized as such. For this examination, the same type tasks and common methods for assessing the quality of performance are used across all of Russia's territory. Since 2009, USE became the only form of final exams at school and the basic form of the entrance exams. There was also the possibility of retaking the USE in subsequent years.

There were some commissions which were formally independent from the universities. Final qualifying exams for students were conducted by the State Examination Commission, whose chairman was not allowed to be an employee of the university. The decision to award bachelor's and master's degrees should be made by the State Examination Commission, whose chairman also was not allowed to be a person who works in the higher education institution that prepared the bachelor or master candidate.

Typically, the protocols of such commissions were not published, but neither were they secret. Access to them might be provided upon request.

Some universities were allowed to conduct extra examinations for admission. The lists of such universities and procedures of such examinations were adopted by the Government of Russia. In 2009, 24 universities were 
entitled to set additional entrance exams on individual specialties. Not all of them invoked this right. For example, the School of International Relations of St. Petersburg State University did not set any additional entrance tests, although it had that right.

Typically, the statutes of universities contained the following standard wording: "The university is a legal entity, has separate property, may on its behalf, acquire economic and moral rights and obligations, as well as act as a plaintiff or defendant in court."

In Russia there were a significant number of precedents of proceedings to universities, including issues related to assessing the legality of any decisions (i.e. by the admission process or dismissal of students).

Of course, there were means of redress. Illegal decisions should be overturned and recognized as invalid. On July 22, 2008, the head of the Federal Service for Supervision in Education and Science said: "If the admission occurred in violation of the law, any student may be dismissed from the university at any stage of his or her education".

However, when in 2009 the Federal Service for Supervision in Education and Science rechecked all the exam works which received the highest grades for USE, the head of the service reported that a quarter of the works didn't meet such high grades, and the test results were sent to the Russian regional examination committees which were then free to decide whether they recognize these results or not.

A centralized system of public financing of education was familiar to Russians. Funds came from taxes, and educational services were provided to the public free of charge. However, in late 2000s, general secondary and vocational educations in particular had become highly paid. The greatest proportion of students in a fully free of charge basis was among the students of primary vocational education $(87.7 \%$ in $2006,88.1 \%$ in 2008$)$. On the stage of primary education, about three quarters of students learned completely free, and among the students of secondary professional education this ratio was $57-59 \%$. The smallest percentage of students studying free of charge was among university students: $57.2 \%$ in 2006 and 56,8\% in 2008 .

For instance, the total expenditure on education in 2005 from the consolidated budget of Russia equaled 801.8 billion rubles. In the 2005-2006 school year spending on education by households reached 405.5 billion rubles. This was about a half of state spending. Vocational education received 22.6 billion rubles more from enterprises. The total expenditure of all economic agents in the education system in the 2005-2006 school year was equal to $1,045.8$ billion rubles. Thus the ratio of private educational expenditures amounted to little more than a third of all spending on it.

Budgetary funds in public universities were about half of the sum of all incomes. In secondary vocational education institutions, they amounted to two-thirds of all incomes. In the system of primary vocational education budgetary funds amounted to more than four-fifths of all incomes. Consequently, other sources of income had different "weight" in these structures. Paid education programs contributed significantly to secondary and higher vocational education: from 31 per cent of budgets of state universities to 81 per cent in private universities, and from 19 to 81 per cent in technical schools. Other sources were less significant (Minimansurovich, 2014). In primary vocational education, commercial educational activities were only in third place. It was surpassed by production activities which brought an average of 6 per cent of income.

As a rule, the universities did not have lump sum budgets. The development of universities was mainly provided by their own extra-budgetary funds. For example, the federal universities should receive a total of 150 billion rubles (more than 3.5 billion Euros) in funding.

Public universities were not autonomous in administering the budget. Income obtained by educational institutions from extra-budgetary sources should be spent only in the statutory purposes: for the provision and development of the educational process. TIS budget assumed tight control over spending on the estimates. State universities must obtain the consent of the Treasury for any spending. Typically, universities had the right to disburse only such cash, property and other possessions that were received as gifts, donations or bequests, as well as in objects and possessions acquired by permitted activities which were recorded on a separate balance sheet.

Autonomous educational institutions were entitled to open accounts in credit institutions, while budgetary institutions could only have personal accounts in the Treasury, which greatly complicated the procedure of disbursement to pay for necessary goods, works and services. Income received by autonomous institutions was theirs to dispose of and might be used to achieve the purposes for which they were created.

Control over the activities of educational institutions with regards to the rendering of paid educational services was overseen by the Federal Antimonopoly Service, as well as public organizations. Control over law 
compliance by educational institutions was overseen by prosecutors.

All the financial activities of universities, including student fees, were monitored by audit bodies of the Ministry of Finance of Russia and the Ministry of Education and Science of Russia. Control over the financial activities of universities that were subject to other ministries, was overseen by the financial authorities of the respective ministries. Control of non-state institutions was overseen by their founders.

Universities of all organizational and legal forms were controlled by the tax authorities as well. Public universities were also controlled by treasuries. The relationship between universities and students studying under the contract were determined by Civil Code, RF Law "On Education", Federal Law "On Higher and Postgraduate Professional Education", RF Law "On Protection of Consumer Rights", the terms of contracts, other legal acts adopted in accordance with the above mentioned laws.

Most public funding was being received by federal universities and national research universities (according to the National Project "Education"). Well-known universities whose brands were created in Soviet times might count at a higher level of extra-budgetary income (the more prestigious the university and the direction of training, the higher the cost of training). These two categories of universities could be considered as "rich". In general, the main body of little-known provincial universities (especially ones established for the last twenty years) was poor and strongly needed extra money.

\section{Discussion}

Different social groups were willing to influence the decision making process in educational institutions by corruption. This situation was typical even for the Russian educational system of Soviet times (Sorokin, 2014). As we have discovered here, those groups were

- people entering the educational institutions and their parents, when they gave bribes for a positive decision on their admission,

- students, when they paid bribes for good grades,

- applicants for degrees, when they paid for "turnkey dissertations", for their defense in a "friendly dissertation council" and for a positive decision from the Higher Attestation Commission,

- employees of educational institutions, when they paid bribes for the distribution of resources within the institutions,

- $\quad$ service organizations and vendors, when they paid kickbacks for contracts on rendering of services and on supply of goods,

- applicants for posts in management of HEIs, when they paid bribes for appointment to the post,

- administrations of educational institutions, when they put pressure (using bribery and blackmail) on the subordinates who made decisions on all above mentioned issues,

- educational authorities, when they exerted pressure (using bribery and blackmail) on the administration of educational institutions to make decisions on all of the above mentioned and other issues.

The processes of making all significant decisions in the universities were usually regulated by legal acts of the Ministry of Education and Science (such as «The Rules of Admission to Universities» etc.) and by the regulations of universities themselves (university statute, statutes on structural subdivisions, the procedure of attestation, etc.) and of their departments. Such regulations were not secret (Burlutskaia, 2014).

But management in Russian universities was mainly hierarchical, bureaucratic. The level of participation of the central administration in decision-making was higher than that of the administration of departments. Decision-making was distributed among various administrative agents. Teachers and students did not actually participate in management. However, teachers were still able to participate indirectly, through the department chairs and academic councils.

\section{Conclusion}

We can see that the legislation and court practice in Russia in the first decade of the 21st century enabled educational institutions to do some kinds of activities in corrupted way. Besides that, the legislation and the corpus of case-law were too complicated. Some laws and decisions made by courts and authorities might contradict one another. State-operated and private educational institutions had different rights and abilities. Thus, Russia needed to gather all the norms concerning activities in educational sphere into one law. This law was adopted in 2012 and came into force in 2013. 
To be effective in struggle against corruption, this law should solve following problems:

- at the policy level-biased allocation of resources,

- at the ministerial level-corruption by administrators, public officials and politicians, accreditation of universities,

- at the university level-issues with personnel (secure opportunities or avoid punishment through petty bribes, others, corruption in teacher recruitment and promotion and tenure lowers the quality of public teaching, admissions (parents paying bribes to ensure their children's school access), graduation (parents paying bribes to ensure their children's good grades and graduation), private tutoring), with allocation of resources (to research: public research commissions, private research commissions, internal research commissions), with publication of results, with conference participation (conference grants).

The question of effectiveness of new Russian educational legislation in solving these problems should be the topic for following research in this field.

\section{References}

BBC. (2012). Experts: law on education leads to commercialization. Retrieved from http://bbc.co.uk/russian/ russia/2012/12/121218_education_law_experts

Borisova, E. (2014). An analysis of the mechanisms of the social control of corruption in the higher education system. Russian Education and Society, 56(4), 27-39. http://dx.doi.org/10.2753/RES1060-9393560402

Burlutskaia, M. G. (2014). Higher education as a means of upward social mobility: The expectations of graduates and the realities of present-day society. Russian Education and Society, 56(4), 52-63. http://dx.doi.org/10.2753/RES1060-9393560404

Codagnone, C., \& Filippov, V. (2000). Equity, exit and national identity in a multinational federation: The 'multicultural constitutional patriotism' project in Russia. Journal of Ethnic and Migration Studies, 26(2), 263-288. http://dx.doi.org/10.1080/13691830050022802

ELA. (2009). ELA-Conference 2009. Retrieved from http://www.lawandeducation.com/download.aspx?c $=. \mathrm{ELA} \& \mathrm{n}=70222 \& \mathrm{ct}=66475 \& \mathrm{e}=212366$

Esyutina, M., Fearon, C., \& Leatherbarrow, N. (2013). The Bologna process in higher education: An exploratory case study in a Russian context. Quality Assurance in Education, 21(2), 145-161. http://dx.doi.org/10.1108/09684881311310683

Greaves, R., \& Scicluna, A. (2010). Commercialization and competition in the education services sector. International Journal for Education Law and Policy, 6(1-2), 13-26.

Luk'Ianenko, M., Polezhaev, O., \& Churliaeva, N. (2013). Engineering education in Russia in an era of changes. Russian Education and Society, 55(4), 58-71. http://dx.doi.org/10.2753/RES1060-9393550404

Luk'yanova, E. (2012). Russian Educational Reform and the Introduction of the Unified State Exam. A View from the Provinces. Europe-Asia Studies, 64(10), 1893-1910. http://dx.doi.org/10.1080/09668136.2012.717361

McCarthy, D. J., \& Puffer, S. M. (2013). Business and management in Russia: A review of the post-Soviet literature and future research directions. European Journal of International Management, 7(1), 74-111. http://dx.doi.org/10.1504/EJIM.2013.052089

Meshcheryakov, K. Y. (2014). Two Decades of Russia's Foreign Policy in Central Asia: Trends and Problems. Middle-East Journal of Scientific Research, 21(1), 63-65. http://dx.doi.org/10.5829/idosi.mejsr.2014.21.01.21228

Minimansurovich, K. A. (2014). Processes of reforming teacher training in modern Russia (Experience of the Kazan Federal University). American Journal of Applied Sciences, 11(8), 1365-1368. http://dx.doi.org/10.3844/ajassp.2014.1365.1368

Osipian, A. L. (2014). Will bribery and fraud converge? Comparative corruption in higher education in Russia and the USA. Compare, 44(2), 252-273. http://dx.doi.org/10.1080/03057925.2012.728374

Pearson. (2012). Index of cognitive skills and educational attainment. Retrieved from $\mathrm{http}$ //thelearningcurve.pearson.com/index/index-ranking

Popkova, E. G., Chashchin, V. V., \& Bogdanov, D. V. (2013). Implementation of the concept of personnel marketing in modern Russia. World Applied Sciences Journal, 22(3), 389-395. 
http://dx.doi.org/10.5829/idosi.wasj.2013.22.03.2926

Rukhadze, N. (2010). Some Aspects of Protection of Right to Education in Georgia. International Journal for Education Law and Policy, 6(1-2), 51-60.

Shirin, S. (2013). Commercialization of education in Russia in the first decade of the 21st century. Procedia-Social and Behavioral Sciences, 106, 631-640. http://dx.doi.org/10.1016/j.sbspro.2013.12.072

Sorokin, A. N. (2014). The Integration of Science, Higher Education and Economy as a Factor of Recovery and Modernization of Soviet National Economy during the First Post-WWII Decades (Case Study of the Activity of the Siberian Physical-Technical Institute (1945-1954)). Bylye Gody, 32(2), 257-261.

Wang, J. Y., Kok, S. K., McClelland, B., \& Kirkbride, J. (2011). The commercialisation of UK higher education and the growing language dynamic in China. International Journal of Learning, 18(1), 87-98.

Wheelock, D., Semukhina, O., \& Demidov, N. N. (2011). Perceived group threat and punitive attitudes in Russia and the United States. British Journal of Criminology, 51(6), 937-959. http://dx.doi.org/10.1093/bjc/azr053

\section{Copyrights}

Copyright for this article is retained by the author(s), with first publication rights granted to the journal.

This is an open-access article distributed under the terms and conditions of the Creative Commons Attribution license (http://creativecommons.org/licenses/by/3.0/). 